lem of costs. It was necessary to request a substantial appropriation from the state legislature to support the program..$^{38}$ And the usual problems have arisen. Reporters have died and transcription of their notes has proved difficult or impossible. In one of these cases, five hundred pounds of notes taken by a deceased reporter have been submitted to six other reporters, none of whom has been able to transcribe them. These problems, of course, arise under any system. But naturally, when the transcripts demanded involve trials held many years before, these difficulties arise much more frequently. Finally, complaints have been heard that the trial judges have shown undue liberality in ordering the entire record of proceedings transcribed, despite the fact that the Rule provided only that portions relevant to petitioners' contentions be transcribed.

These difficulties, and others which might be mentioned, ${ }^{39}$ have appeared. There is no point in denying that some of them are serious. But certainly, it is not too soon to conclude that they are not insuperable. Surely, there is no reason to believe that Illinois will be unable to deal with these problems as satisfactorily as they have been dealt with in the federal system and in twothirds of the states. There is reason, too, to hope and expect that ultimately the result of this effort will be a higher quality of criminal justice in Illinois.

${ }^{35}$ H.B. 1346, 1954 session of the Illinois General Assembly, appropriating a sum of $\$ 250,000$, passed the legislature and was approved by the Governor.

${ }^{39}$ One of the weaknesses in Rule 65-1 may be the failure to specify the right of petitioner to have counsel appointed in his behalf to assist in the preparation of the petition for a transcript and in fulfilling the other requirements of the Rule. Compare the recently adopted Act 239 of the Territory of Hawaii, approved by the Governor of the Territory of Hawaii, June $3,1957$.

\title{
THE EFFECT OF GRIFFIV v. ILLINOIS ON THE STATES' ADMINISTRATION OF THE CRIMINAL LAW
}

The United States Supreme Court's decision in Griffin v. Illinois ${ }^{1}$ established a new Fourteenth Amendment constraint upon state court criminal administration, and makes advisable a re-evaluation of time-honored practices and statutes regarding the state's obligation to the indigent prisoner who seeks an appeal from his conviction. In its narrowest scope the decision holds that a state which requires a transcript of record for appellate review of criminal convictions must furnish the same to an indigent prisoner who pursues a timely appeal from his conviction. ${ }^{2}$ But the Court's rationale portends a greater significance for the decision than the mere furnishing of transcripts for appeal:

1351 U.S. 12 (1956). The decision provoked a rash of comments in law reviews. See Fairman, The Supreme Court 1955 Term, 70 Harv. L. Rev. 83, 121-29 (1956); Criminal Procedure -Due Process and Equal Protection Held To Require Free Transcripts for Indigent Convicts, 1956 Ill. L. Forum 501; Constitutional Law-Post-Conviction Due Process-Right of Indigent to Review of Non-Constitutional Trial Errors, 55 Mich. L. Rev. 413 (1957); Constitutional Law: Due Process and Equal Protection-Right of an Indigent Defendant to a Transcript of the Trial, 4 U.C.L.A. L. Rev. 274 (1957).

2 It is unclear from the Court's opinion whether its holding was premised on the Due Process or Equal Protection Clauses or both. See discussions in Mich. L. Rev., op. cit. supra note 1, at 416-18; Harv. L. Rev., op. cit. supra note 1, at 126-29. 
[T]o deny adequate review to the poor means that many of them may lose their life, liberty or property because of unjust convictions which appellate courts would set aside. Many States have recognized this and provided aid for convicted defendants who have a right to appeal and need a transcript but are unable to pay for it. A few have not. Such a denial is a misfit in a country dedicated to affording equal justice to all and special privileges to none in the administration of its criminal law. There can be no equal justice where the kind of trial a man gets depends on the amount of money he has. Destitute defendants must be afforded as adequate an appellate review as defendants who have money enough to buy transcripts. ${ }^{3}$

The implications of the Court's emphasis on "adequate appellate review" will be examined after a discussion of the more direct effect of the decision-its bearing on state practices ${ }^{4}$ regarding the furnishing of transcripts.

At the time of the Griffin decision (April 23, 1956) the states pursued four different policies with respect to furnishing transcripts of testimony for appellants in criminal proceedings. The various practices, reproduced in fuller detail in Appendix I, infra, may be summarized as follows:

TRANSCRIPTS FURNISHED OR AVAILABLE

FREE OF CHARGE TO (as of April, 1956)

1. All defendanis in all criminal cases

$\begin{array}{ll}\text { California } & \text { Massachusetts } \\ \text { Georgia } & \text { Ohio } \\ \text { Louisiana } & \text { Wisconsin }\end{array}$

2. All indigent defendants convicted of any criminal offense

Arizona New Mexico

Arkansas New York

Connecticut Oklahoma

Florida Oregon

Idaho Pennsylvania

Indiana Rhode Island

Iowa South Carolina

Kentucky South Dakota

Missouri Texas

Mississippi Utah

Montana Virginia

Nebraska Washington

Nevada West Virginia

New Hampshire

3. All indigent defendants convicted of a capital offense

Alabama

Colorado

Maine*

Delaware

Maryland*

Illinois*

New Jersey*

North Carolina

${ }^{3}$ Griffin v. Illinois, 351 U.S. 12,19 (1956).

4 For a discussion of the Griffin decision's significance for the federal practice see United States v. Sanders, 142 F.Supp. 638 (D. Md., 1956); Mich. L. Rev., op. cit. supra note 1, at 425-30; discussion of United States v. Johnson at p. 168 infra. 
4. No defendants in any criminal proceeding

Kansas

Michigan

Minnesota*

North Dakota
Tennessee*

Vermont

Wyoming

* See Appendix II for changes proposed or accomplished.

For the states in group 3 and 4 above, which furnish the transcript not at all, or only for capital convictions, the Griffin decision poses an immediate problem. There are, however, several real and potential distinctions which are significant in assessing the implications of that decision, not only for the states immediately concerned, but for the others as well.

\section{LIMITATIONS AND IMPLICATIONS CONCERNING FURNISHING OF TRANSCRIPTS}

1. States are not required to furnish appellate review, rather "a State that does grant appellate review can [not] do so in a way that discriminates against some convicted defendants on account of their poverty." 5

The Supreme Court took care to reaffirm the established rule that "a State is not required by the Federal Constitution to provide appellate courts or a right to appellate review at all. See, e.g., McKane v. Durston, 153 U.S. 684, 687-88." In Illinois, ${ }^{7}$ as well as in the forty-seven other states, however, "[a]ppellate review has now become an integral part of the ... trial system for finally adjudicating the guilt or innocence of a defendant." "Consequently," the opinion continues, "at all stages of the proceedings the Due Process and Equal Protection Clauses protect persons like petitioners from invidious discriminations." 8

In Illinois writs of error in criminal cases are writs of right. ${ }^{9}$ In other states the appellate court has discretion in whether to allow an appeal. ${ }^{10}$ In declaring that appellate review may not be granted in a manner which subjects the poor to "invidious discriminations," the Griffin decision seems to apply as well to the conditions on which discretionary appeal is extended as to the rules on which appeal as of right is administered. ${ }^{11}$

2. States are not required to furnish a transcript of testimony where that item is not necessary to secure adequate appellate review.

In Illinois full direct appellate review is available only upon the appellant's furnishing the appellate court with a bill of exceptions or transcript of proceedings at the trial. ${ }^{12}$ Counsel for Illinois conceded in the Griffin case that "it is

${ }^{5}$ Griffin v. Illinois, 351 U.S. 12, 18 (1956). 'Ibid.

${ }^{7}$ The turbulent history of post-conviction remedies in Illinois is discussed in Ill. L. Forum, op. cit. supra note 1.

${ }^{8}$ Griffin v. Illinois, 351 U.S. 12, 18 (1956).

${ }^{9}$ Ill. Rev. Stat. (1955) c. $38, \$ 769.1 . \quad{ }^{10}$ E.g., Mrich. Rev. Stat. (1954) $\$ 28.1100$.

11 Criminal Procedure-State Failure to Provide Free Transcripts to Indigent Criminals, 3 Wayne L. Rev. 62, 64 (1956).

12 Illinois Supreme Court Rule 65. 
sometimes impossible to prepare such bills of exceptions or reports without a stenographic transcript of the trial proceedings."13 Since the transcript was seen as the sine qua non of appellate review, the Court held that a state could not decline to furnish it to the indigent.

In many states, however, a transcript of trial proceedings is not a prerequisite to appellate review. Some states make no provision for transcribing testimony. ${ }^{14}$ In those states, and in others, appeals are commonly heard (1) from a narrative bill of exceptions prepared during the trial by a reporter, the clerk, or counsel,,$^{15}$ or (2) by means of a bystanders' bill of exceptions prepared from the memory of one present at the trial. ${ }^{16}$ With respect to those states which require no transcript the Supreme Court was careful to state-with one important exception-that no transcript need be furnished:

We do not hold, however, that Illinois must purchase a stenographer's transcript in every case where a defendant cannot buy it. The Supreme Court may find other means of affording adeguate and effective appellate review to indigent defendants. ${ }^{17}$ [Italics added.]

From the Supreme Court's repeated emphasis of the words adequate appellate review ${ }^{18}$ it may be concluded that there are circumstances where even those states which now require no transcript of testimony for appellate review may be called upon to furnish transcripts to the indigent. It is hard to imagine "adequate and effective appellate review" without a full transcript of record when the error asserted is insufficiency of evidence. ${ }^{19}$ Similarly, it is difficult to imagine that a bystander's bill would furnish an "adequate and effective appellate review" of an erroneous instruction. It is unnecessary to recount other examples which come readily to mind.

There is one limitation to this observation. Since the states are not obligated to have appellate review at all, and since the Griffin decision sought only to eliminate "invidious discriminations" between poor and rich, states not requiring transcripts for review would seem obligated to furnish them only where their appellate courts will utilize transcripts of record to extend the scope

${ }^{13}$ Griffin v. Illinois, 351 U.S. 12, 13-14 (1956).

${ }^{14}$ At least two, and perhaps more, states provide no court reporter to make an official record of all that transpires at the trial: Kentucky (this may be inferred from the case discussed in note 16 infra); Louisiana (Ltr. of Jack P. F. Gremillion, Att'y Gen'l of Louisiana, dtd. Jan. 22, 1957).

${ }^{15}$ E.g., Kansas (Appendix I Group 4); Louisiana (note 14 supra); Mrinnesota (see State v. Haller, 247 Minn. 571,78 N.W.2d 389 [1956], stating that a transcript is not necessary in all cases); New Mexico, Tennessee and Virginia (see Brief for Petitioner, at 86, Griffin v. Illinois, 351 U.S. 12 [1956], citing letters from officials in those states to the effect that a narrative bill will suffice or [Tennessee] that a majority of criminal cases are heard on narrative bill.)

${ }^{16}$ A case involving and discussing the bystanders' bill, still in use in Kentucky, is Meredith v. Commonwealth, 296 S.W.2d 705 (Ky., 1956).

${ }^{17}$ Griffin v. Illinois, 351 U.S. 12, 20 (1956). The Court went on to suggest that "it may be" that a bystander's bill "could be used in some cases." Ibid.

${ }^{18}$ Id., at 13 (twice), 16, 18, 19, 20.

${ }^{19}$ Ltr. of Jack P. F. Gremillion, Att'y Gen'l of Louisiana, dtd. Jan. 22, 1957. 
of review for those defendants able to pay the bill. If all appellate review is limited to a mandatory record (indictment, arraignment, plea, verdict and sentence) ${ }^{20}$ there would seem to be no circumstances under which the Griffin case would require that a transcript be furnished.

3. States are perhaps not required to furnish a transcript to one convicted of a comparatively minor criminal offense.

One discussion of the Griffin decision ${ }^{21}$ points out that the petitioners there sought to review a conviction for armed robbery, in Illinois a very serious crime carrying a maximum penalty of life imprisonment. Drawing an analogy to the due process decisions on right to counsel, which presently make a well known distinction between the right to counsel of those charged with capital ${ }^{22}$ and non-capital offenses, ${ }^{23}$ the suggestion is made (though not approved) that the Griffin transcript requirement might not apply to convictions for less serious crimes. ${ }^{24}$ Certainly the narrow majority in favor of the Griffin decision (5-4), and the circumstance that a considerable number of states furnish transcript only for those convicted of felonies, ${ }^{25}$ suggest some limitation according to the seriousness of the penalty involved.

4. For the future, states are probably only required to furnish a transcript for a timely appeal.

The Supreme Court has been solicitous of state rules denying review by an out-of-time appeal..$^{26}$ Since it can hardly be supposed that states would be required to furnish a transcript for an appeal they are not obligated to hear, for post-Griffin convictions the decision requires no transcript for a defendant properly aware of his rights ${ }^{27}$ whose time for appeal has expired before he makes application for the transcript.

5. For convictions already concluded there are authoritative indications that Griffin v. Illinois may justify federal court intervention requiring states to furnish appellate review or discharge the prisoner.

Does Griffin v. Illinois mean that presently confined prisoners who, due to their poverty, were unable to have direct review of their convictions, have a

${ }^{20}$ The mandatory record is available free of charge to the defendant in Illinois. Griffin $v$. Illinois, 351 U.S. 12, 13 n. 2 (1956).

21 Mich. L. Rev., op. cit. supra note 1, at 419-20.

22 Powell v. Alabama, 287 U.S. 45, 73 (1932).

${ }^{23}$ Betts v. Brady, 316 U.S. 455, 472-73 (1942).

24 Mich. L. Rev., op. cit. supra note 1.

${ }^{25}$ Georgia, Maine (proposed), Tennessee (proposed), Texas and Virginia. See Appendices I and $I I$, infra.

${ }^{26}$ E.g., Brown v. Allen, 344 U.S. 443, 453-54, 482-86 (1933) (refusal of state supreme court to review for discrimination in jury lists and coerced confessions convictions resulting in death sentences, when appeal one day out-of-time: held, not violative of equal protection clause of Fourteenth Amendment).

${ }^{27}$ As subsequent discussion will indicate (p. 166 et seq., infra, the indigent defendant must be instructed adequately in his right to a free transcript, or the state's time limitations on review of his conviction may be to no avail. 
constitutionally protected right to be supplied with the prerequisites for, and opportunity for, that review through habeas corpus or some equivalent postconviction remedy? ${ }^{28}$ The Supreme Court of Oregon, at the date of this writing the only court to have considered the issue, concluded that habeas corpus "presented more potent ground for relief" than the direct review present in the Griffin case. ${ }^{29}$

When similar problems were raised by the Supreme Court's decision regarding right to counsel in the federal courts, ${ }^{30}$ the decisions at first held that counsel had been waived when the defendant had not requested it. ${ }^{31}$ In Walker 2. Johnston, ${ }^{32}$ however, the Supreme Court seems to have done away with this "waiver" rationale by reversing a federal court's dismissal of a habeas corpus petition by a prisoner tried without counsel three years before the Zerbst case. The court held that if the petitioner "was ignorant of his right to such aid, was not interrogated as to his desire or informed of his right, and did not knowingly waive that right, . . . he was deprived of a constitutional right." ${ }^{33}$ The rightto-counsel problem has apparently subsided without any other notable developments.

A 1950 Supreme Court decision, Dowd $v$. Cook, ${ }^{34}$ reinforces the conclusion that prisoners convicted prior to the Griffin decision can secure a review of their convictions through habeas corpus petitions in a federal court. In that case a state prisoner who had been prevented in 1933 from filing his "prepared proper appeal papers" by a restrictive prison rule, secured from a unanimous Court a remand of his federal court petition for habeas corpus, with instructions "to allow the state a reasonable time in which to afford respondent the full appellate review he would have received but for the suppression of his papers, failing which he shall be discharged." ${ }^{35}$ Where a prisoner has made affirmative efforts

${ }^{28}$ This matter is discussed in Fairman, The Supreme Court 1955 Term, 70 Harv. L. Rev. $83,128-29$ (1956), with the conclusion that habeas corpus is probably available to "prisoners who were unable to appeal because of cost requirements such as that struck down in Griffin." Accord: Constitutional Law-Post-Conviction Due Process-Right of Indigent to Review of Non-Constitutional Trial Errors, 55 Mich. L. Rev. 413, 419-20 (1957).

${ }^{29}$ Barber v. Gladden, —- Ore. —- - 298 P.2d 986, 990 (1956) (involving indigent appellant's right to payment of costs on appeal): "In the pending case the plaintiff brought habeas corpus, which necessarily involved claims of violation of his constitutional rights rendering the judgment of conviction not only erroneous, but void. We feel forced to the conclusion that the United States Supreme Court, as at present constituted, would hold that the case at bar presented more potent ground for relief than appeared in Griffin v. Illinois."

${ }^{30}$ Johnson v. Zerbst, 304 U.S. 458 (1938).

31 E.g., Odom v. Aderhold, 115 F.2d 202 (C.A. 10th, 1940), cert. denied 312 U.S. 683 (1941). See discussion in Holtzoff, The Right of Counsel under the Sixth Amendment, 20 N.Y.U.L.Q. Rev. 1, 10-13 (1944).

32312 U.S. 275 (1941).

${ }^{33}$ Id., at 286. Accord: Robinson v. Johnston, 50 F.Supp. 774 (N.D. Cal., 1943). See Griffin v. Illinois, 351 U.S. 12, 25 (Frankfurter, J., concurring) (no waiver of rights by prisoners justified in assuming that their restriction was a valid exercise of the state's power).

34340 U.S. 206 (1951).

${ }^{35} \mathrm{Id}$., at 210. 
toward appeal which have been frustrated by the state's failure to respond to his request for a transcript the Dowd case seems to be the squarest holding that habeas corpus will be available in the federal court. Where the prisoner has not requested a transcript, or where he has made no efforts to prepare an appeal, while his claim is not so strong, the Walker v. Johnston holding that a knowing waiver of constitutional rights is required strongly suggests that relief may also be had under those circumstances. In post-Griffin state proceedings involving the transcript of a trial concluded before the Griffin decision, motions for transcripts have been both granted ${ }^{36}$ and denied, ${ }^{37}$ without any apparent significance being attached to the circumstance that the trial preceded Griffin $v$. Illinois.

The deluge of petitions which have been and are yet to be touched off by the possibility of this interpretation of the Griffin decision present a pressing problem, one of which the Supreme Court, as well as the lower courts whose dockets they crowd, cannot be unaware. The solution proposed by the concurring opinion of Mr. Justice Frankfurter, ${ }^{38}$ namely, prospective application of the decision, was not mentioned in the "majority" (four justices) opinion, and the dissenters (four justices) declared that "Mr. Justice Black's opinion is not limited to the future." 39 The ambiguity this created led the Attorneys General of twelve states ${ }^{40}$ to petition for rehearing and clarification, seeking as a minimum that the decision be limited to prospective application. ${ }^{41}$ The petition was summarily denied. ${ }^{42}$

${ }^{36}$ People v. Jackson, 2 N.Y.Misc.2d 521, 522, 523, 152 N.Y.S.2d 893, 894, 895 (Herkimer Co. Ct., 1956) (denial of defendant's motion, accompanied by pauper's oath, to obtain "copy of the stenographic minutes of his [1954] trial for the purpose of further review of his case," held "a denial of equal protection in [sic] due process"). Barber v. Gladden, - Ore. -, 298 P.2d 986 (1956) (indigent defendant's appeal from denial of writ of habeas corpus to review April 17, 1956 conviction [four days before the Grifin case]: held, statutory requirements of appeal bond waived).

${ }^{37}$ New York v. Strong, 159 N.Y.S.2d 351, 352 (King's Co. Ct., 1957) (motion for transcript of defendant's unappealed 1955 felony conviction granted Sept. 20, 1956, but order rescinded and motion denied on reargument Jan. 15, 1957, because Appellate Division in unreported decision of Oct. 3, 1956 had denied a similar motion by defendant). New York v. Lumpkin, 158 N.Y.S.2d 610 (Ct. of Gen. Sess., N.Y. Co., 1956) (motion for transcript of unappealed 1953 larceny conviction denied because (1) defendant failed to indicate why he wanter the minutes " $C$ ertainly he should not be given the minutes merely because it might make interesting reading for him."], and (2) after his trial he had failed to pursue his right to appeal as an indigent. The court indicated willingness to reconsider the motion if the defendant proposed to pursue "any particular pracedure... in which the minutes are necessary").

${ }^{38}$ Griffin v. Illinois, 351 U.S. 12, 25-26 (1956).

${ }^{39}$ Id., at 29.

${ }^{40}$ Connecticut, Georgia, Illinois, Kentucky, Maryland, New Hampshire, New Mexico, Tennessee, Texas, Virginia, Washington and Wisconsin. (Note 41 infra.)

"Petition for Rehearing, at 5, and Joinder of Attorneys General, at 2, Griffin v. Illinois, 351 U.S. 12 (1956).

42351 U.S. 958 (1956). The idea of prospective application of the Griffin decision got a cool response from one federal judge. "I do not find express support for this view in the opinion of 
Nevertheless, since a majority of the court either did not want the states fettered with the requirement of furnishing transcripts (the four dissenters) or wanted that requirement to be exclusively prospective in application (Justice Frankfurter, concurring) it may be anticipated that some limitations may be erected with respect to trials already concluded. Certiorari has been granted in a decision which perhaps offers some opportunity for clarification. ${ }^{43}$ Just what limitations, if any, there may be awaits the pleasure of the Court, and in the interim it may be anticipated that no little amount of inconvenience will be incurred on the part of those who must hear, and answer, the multitude of petitions which are and will be forthcoming.

6. States are not required to furnish a transcript to a defendant who has no reasonable basis for appeal, but there are indications that the trial court's decision on that issue must be reviewable, and that some portion of the record must be furnished the defendant for purposes of that review.

Many of the states providing indigent defendants with transcripts put the matter in the discretion of the trial court. So long as an indigent defendant gets his transcript whenever he has a reasonable basis for appealis there can be no objection to this approach..$^{45}$ The right to a free transcript in federal trials is also made discretionary with the district court, ${ }^{46}$ a provision never thought to be violative of Fifth Amendment due process.

The finality of a federal court's decision on whether a convicted criminal has such a basis for appeal as to require furnishing him with the free transcript provided indigent prisoners by federal law ${ }^{47}$ was the subject of Johnson $v$. United States, ${ }^{48}$ the Supreme Court's only decision on the transcript problem since the Griffin case. A federal district court denied an indigent defendant's petition for leave to appeal in forma pauperis (government required to furnish counsel and

Mr. Justice Black for the majority of the Court. And in this connection I have read with interest what Mr. Justice Frankfurter had to say in his concurring opinion." United States v. Sanders, 142 F.Supp. 638, 646 (D. Md., 1956).

${ }^{43}$ Eskridge v. Schneckloth, 353 U.S. 922 (1957) (granting petition for leave to proceed in forma pauperis, and petition for writ of certiorari to Supreme Court of Washington [unreported decision]). This case is described as involving "the issue of furnishing a free transcript of the criminal trial proceedings for a convicted indigent. . . "Ltr. of John J. O'Connell, Att'y Gen'l of Washington, dtd. Jan. 23, 1957.

${ }^{44} \mathrm{It}$ is worthy of note that the Griffin rule requires a transcript to be furnished to defendants who assert any trial error which would justify reversal, and is not limited to those errors which offend constitutional provisions. In the Griftin case itself the court assumed that no such errors were involved, since if that had been the case the petitioners could have obtained a free transcript by a petition under the Illinois Post-Conviction Act. Griffin v. Illinois, 351 . U.S. 12, 15-16 (1956).

45 Mich. L. Rev., op. cic. supra note 28 , at 423 .

${ }^{46} 62$ Stat. 922, 954 (1948), as amended, 28 U.S.C.A. $\$ 753$ (f) (1949), \$1915(b) (1950).

47 Ibid.

${ }^{48} 352$ U.S. 565 (1957). 
transcript), according to its statutory prerogative. ${ }^{49} \mathrm{~A}$ similar motion in the Court of Appeals was likewise denied..$^{50}$ That court held that the Griffin decision did not prevent a federal court from denying leave to appeal in forma pauperis when the appeal was frivolous, and that the district court's decision was final absent a showing of action without warrant or not in good faith. In dissent, Judge Frank urged that the Griffin decision applied to the federal courts via the Fifth Amendment; that a refusal to furnish the transcript constitutes a discrimination because it meant that only the rich man can pursue a frivolous appeal or be assured that a meritorious appeal will not be overlooked; and that in any event the transcript must be furnished for an appeal from the denial of the motion, since only with the transcript can the appellate court decide whether the denial was in good faith.

Without reference to Griffin 2 . Illinois the Supreme Court reversed, for failure to assign counsel to assist petitioner in prosecuting the application for leave to appeal, and for failure to provide the petitioner with an "adequate means of presenting it with a fair basis for determining whether the District Court's certification was warranted. ..."si Speaking per curiam, the Court's remarks on the last issue shed some light on what will be expected of state courts in administering the Griffin decision:

Finally, either the defendant or his assigned counsel must be enabled to show that the grounds for seeking an appeal from the judgment of conviction are not frivolous and do not justify the finding that the appeal is not sought in good faith. This does not require that in every such case the United States must furnish the defendant with a stenographic transcript of the trial. It is essential, however, that he be assured some appropriate means-such as the district judge's notes or an agreed statement by trial counsel-of making manifest the basis of his claim that the District Court committed error in certifying that the desired appeal was not pursued in good faith."52

Although these instructions are issued for the federal courts, it may be expected that they are not without significance for the states. If the Supreme Court is as unwilling to have the final decision on the meritoriousness of an appeal lodged in the state courts as the Johnson case indicates it unwilling to have the finality of that decision repose in its own highly regarded district courts, then some review of state trial court decisions on the refusal of transcripts must be provided. And if that review is provided, then the Johnson decision seems to indicate the minimum terms on which it may be extended: Every defendant who petitions for a transcript and is willing to pursue its denial to the appellate court must be furnished with some "appropriate means . . . of making manifest the basis of his claim. . . " ${ }^{53}$ The prospect is not a happy one for state criminal law administration.

49 When "the trial court certifies in writing that it [the appeal] is not taken in good faith." 62 Stat. 954 (1948), as amended, 28 U.S.C.A. \$ 1915(a) (1950).

${ }^{50}$ United States v. Johnson, 238 F.2d 565 (C.A. 2d, 1956).

51 Johnson v. United States, 352 U.S. 565, 566 (1957).

52 Ibid.

63 Ibid. 
InPLications For the Other COSTS OF Appeal and Trial

Though the Supreme Court was careful to avoid any reference to the other expenses involved in securing "adequate and effective appellate review" its decision has obvious implications apart from the expense of transcripts. Generally there are three principal costs involved in appellate review: $:^{54}$ (1) preparation of notices, motions, pleadings, documents, and transcripts; (2) filing fees and/or appeal bond; (3) counsel.

1. Cosis.-The Oregon Supreme Court has held that Griffin v. Illinois requires the state to assume the cost of an appeal bond for an indigent appellant. ${ }^{55}$ The decision can hardly be criticized. If states must furnish indigents with the transcripts necessary for appellate review, they surely must also foot the bill for the incidental costs necessary to obtain that review..$^{56}$

2. Counsel.- The Supreme Court's emphasis on the obligation of states to see that indigent defendants, as well as the more opulent, get "adequate and effective appellate review" 57 portends a requirement that the indigent appellant 'je provided with counsel. Certainly there are circumstances under which the 'adequacy" and "effectiveness" of appellate review would be seriously impaired, if not prevented, where the indigent appellant was unrepresented. If the Griffin decision has established the above-quoted language as the standard, some change in the doctrines of right to counsel may be forthcoming. With respect to the federal courts, where, it must be noted, a more extensive right to trial counsel has heretofore prevailed, ${ }^{58}$ the Supreme Court has already ruled that an indigent prisoner who seeks appellate review must be provided with counsel..$^{59}$

Despite its excessively broad language, a careful reading of the Griffin opinion reveals the care with which the Court avoided any reference to the counsel problem. Indeed, in the passage quoted above,${ }^{60}$ where the Court's language is especially sweeping, the final clause ("who have money enough to buy transcripts") seems so out of harmony with the preceding sentences to suggest its insertion after the original writing, perhaps to meet an objection that the passage was too broad for a court which did not purport to decide the counsel question. ${ }^{61}$ At any rate, the rationale of the decision is very suggestive of a forth-

54 A.L.I. Code of Crim. Proc. $\$ 447$. Consult Right of Indigent Defendant in Criminal Case to Aid of State as Regards New Trial or Appeal, 100 A.L.R. 321 (1936), discussing state practices regarding the various costs of appeal, and citing a multitude of cases.

${ }^{55}$ Barber v. Gladden, —- Ore. —-, 298 P.2d 986 (1956) (holding state statute requiring appeal bond "to that extent and in this application, unconstitutional").

${ }^{56}$ The dissenters in Griffin v. Illinois, 351 U.S. 12, 38 (1956), interpreted the majority opinion to require the state to "bear the cost of appeals for indigents."

57 Note 18 supra.

${ }^{58}$ Compare Johnson v. Zerbst, $30 \pm$ U.S. 458 (1938), with Betts v. Brady, 316 U.S. 455 (1942).

${ }^{59}$ Johnson v. United States 352 U.S. 565 (1957). $\quad{ }^{60}$ See p. 162 supra.

${ }^{61} \mathrm{It}$ is interesting in this connection that in a case supposed in Mr. Justice Frankfurter's opinion, both parties have counsel. Griffin v. Illinois 351 U.S. 12, 25 (1956). 
coming requirement that indigents be furnished with counsel for an appeal. The New York Court of Appeals has already held, in a per curiam opinion, that a failure to appoint counsel for an indigent appellant "prevented an effective use of the right to appeal in violation of the constitutional guarantees of due process and equal protection. [N.Y. Const., Art. I, $\$ \$ 6,11.]^{\prime 62}$

One vital distinction has been pointed out between the Griffin transcript decision, and the right-to-counsel-on-appeal situation:

While it is undeniable that the assistance of skilled counsel may be of inestimable value to a defendant, the presence of counsel is not a sine qua non to access to the courts, as was the availability of the transcript in the Griffin case. ${ }^{63}$

While this distinction has undeniable force, it disregards the Supreme Court's emphasis on "adequate and effective appellate review."

Finally, if the Griffin decision does include within its rationale the mandatory appointment of counsel to assist indigents in appealing their conviction, this surely requires a re-evaluation of well-established notions of right to counsel for irial. The aid of counsel can hardly be more important for an appeal from a conviction than in the proceedings which lead to that conviction. Justice Walter V. Schaefer of the Illinois Supreme Court has suggested the implications of the Griffin decision in this context:

The analogy to the right to counsel is very close indeed: if a state allows one who can afford to retain a lawyer to be represented by counsel, and so to obtain a different kind of trial, it must furnish the same opportunity to those who are unable to hire a lawyer. Since indigence is constitutionally an irrelevance, it would seem that a successful argument might be based upon the proposition that the defendant by reason of his poverty is deprived of a right available to those who can afford to exercise it. ${ }^{64}$

A revamping of the right-to-counsel doctrine is a job too momentous to be undertaken obiter. For the present the old authorities stand relatively unimpaired. Nevertheless, Griffin v. Illinois is doctrinally inconsistent with the rightto-counsel rules to the extent that they allow an indigent to be tried or forced to appeal without counsel when a more adequate and effective defense is available to those able to obtain the aid of counsel. In squaring these doctrines some extension of the present right to counsel may be expected.

${ }_{62}$ People v. Kalan, 2 N.Y.2d 278, 280, 140 N.E.2d 357, 358 (1957). The Griffin opinion was not cited.

63 Mich. L. Rev., op. cit. supra note 28 , at 420.

64 Schaefer, Federalism and State Criminal Procedure, 70 Harv. L. Rev. 1, 10 (1956). 


\section{APPENDIX I}

STATE LAWS CONCERNING FURNISHING DEFENDANTS IN CRIMINAL PROCEEDINGS WITH THE NECESSARY TRANSCRIPTS FOR APPELLATE REVIEW (AS OF THE TIME OF GRIFFIN $V$. ILLINOIS, APRIL 23, 1956)

Group 1. Furnished or Available without Charge to All Persons Convicted of a Criminal Offense

California Cal. Gov't. Code Ann. (Derring, 1951) §69952 (Supp., 1955) ("In criminal cases in which the court specifically so directs"); People v. Smith, 34 Cal.2d 449, 211 P.2d 561 (1949) ("matter of right").

Georgia Ga. Code Ann. (1953) \$27-2401 (provides for copy for court which is made available for use by defendants in felony cases as a matter of practice. Ltr. of Eugene Cook, Att'y Gen'l of Georgia, dtd. Jan. 23, 1957.) If the conviction is affirmed the State may recover the cost from defendants able to pay. Ga. Code Ann. (1953) § 24-3104.

Louisiana La. Rev. Stat. (1950) $\$ 15: 547$. A bill of exception is all that is required for appeal. State v. Proctor, 165 La. 584, 115 So. 759 (1928). A "transcript" consisting of "The objections to the questions asked, the answer thereto and the Judge's ruling thereon" is "lodged in the appellate court" and "available" to the accused. Ltr. of Jack P. F. Gremillion, Att'y Gen'l of Louisiana, dtd. Jan. 22, 1957. If a defendant wants all the testimony recorded he must secure and pay for a reporter. La. Rev. Stat. (1950) $\$ 15: 555$.

Massachusetts Mass. L. Ann. (1956) c. 278, §33A (mandatory for murder or manslaughter convictions; discretionary for other felonies.) In all criminal cases the papers relative to a question of law which arises in the trial court are filed in the appellate court at the state's expense. Mass. L. Ann. (1956) c. 278, $\$ 33$.

Olio Ohio Rev. Code (1955) Tit. 23, $\$ \$ 2301.24,2301.25$ (expense of preparation is taxed as costs.). Compare Ohio Rev. Code (1955) Tit. 29, \$2953.03; Poppa v. Wanamaker, 128 N.E.2d 764 (Ohio C.A., 1954) (semble).

Wisconsin Wis. Stat. (1955) \$252.20. (provides for copy for court which is made available for use by convicted defendants as a matter of practice. Ltr. of Steward G. Honeck, Att'y Gen'l of Wisconsin, dtd. Mar. 25, 1957).

Group 2. Furnished or Available without Charge to ali Persons Convicted of a Crimisal Offense Who ARe without Means To Pay

Arizona Ariz. Rev. Stat. (1956) \$13-1714 ("without means or wholly unable to pay").

Arkansas Ark. Stat. Ann. (1947) \$22.357.

Connecticut Conn. Gen. Stat. (1949) §8850.

Florida Fla. Stat. (1955) \$924.23.

Idako Idaho Code \$1-1105 (Supp., 1957).

Indiana Ind. Stat. (1946 Repl.) \$4-3511 (available only for a timely appeal). 
Iox'a Iowa Code Ann. (1950) $\$ 793.8$ ("The statute does not apply to habeas corpus proceedings which are civil in nature." Ltr. of Norman A. Erbe, Att'y Gen'l of Iowa, dtd. Jan. 23, 1957).

Kentucky Ky. Rev. Stat. (1955) $\$ \$ 28.440(1), 28.450(2), 28.460(2)(a)$.

Mississippi Miss. Code Ann. (1956) $\$ \$ 1174,1175,1640$.

Missouri Mo. Rev. Stat. (1952) $\$ 485.100$ (Supp., 1956).

Montana Mont. Rev. Code (1947) \$94-8112.

Nebraska Neb. Rev. Stat. (1948) $\$ 24-342$.

Nerada Nev. Comp. Laws (1929) §11029.03 (Supp., 1943-49) (discretionary with the court ["the court shall have the power to. ...."]).

New Hampshire N.H. Rev. Stat. (1955) \$519.26. Although there are no statutes specifically furnishing this item to the indigent defendant the expense of obtaining a transcript is probably a cost for which an appointed counsel would be reimbursed. Ltr. of William E. Lovejoy, Law Ass't to the Att'y Gen'l of New Hamsphire, dtd. April 18, 1957.

New Mexico Although there are no statutes or court decisions regarding furnishing transcripts to indigent defendants, "we may conclude from the way in which free transcripts have been given to affiants of pauper affidavits that our courts have tacitly extended such privilege [in criminal actions]." Ltr. of Howard M. Rosenthal, Ass't Att'y Gen'l of New Mexico, dtd. Feb. 7, 1957.

New York N.Y. Consol. L. Ann. (MicKinney, 1957 Supp.) Tit. VIII, $\$ 456$.

Oklahoma Okla. Stat. (Supp., 1956) Tit. 20, \$111 (discretionary with the court).

Oregon Ore. Rev. Stat. (1955) $\$ 21.470$ (discretionary with the court ["if in his opinion justice will be thereby promoted. ...']).

Pennsylrania Pa. Stat. Ann. (Purdon, Supp., 1956) Tit. 17, $\$ \$ 1809,1810$ (discretionary with the court except where accused has been convicted of first-degree murder, whereupon the state bears all the costs of appeal).

Rhode Island State v. Hudson, 55 R.I. 141, 179 Atl. 130 (1935) (discretionary with the court).

South Carolina S.C. Code (1952) \$15-1903.

South Dakota S.D. Code (1939) $\$ 34.3903$ (printed record not necessary; discretionary with the court. ["in which the Court deems it essential to the protection of the substantial rights of the defendant. ..."']).

Texas Tex. Code Crim. Proc. Ann. (Vernon, 1950) $\$ 760$ (6) (limited to felony cases).

Utah Utah Code Ann. (1953) \$78-56-8 (discretionary with the court).

Virginia Va. Code (Supp., 1956) \$17-30.1 (limited to felony cases; where the conviction is upheld on appeal the expense "shall be assessed against the defendant").

Washington Wash. Rev. Code (1951) \$2.32.240 (discretionary with the court ["if in his opinion justice will thereby be promoted. ...']).

West Virginia W.Va. Code (1955) §5251(1).

Grout 3. Furnished or Available without Charge to All

Persons without Means To Pay Who Are ConVICTED of a CAPITAI OFFENSE

Alabama Ala. Code (1940) Tit. 15, §382(12) (Supp., 1955) (where the death sentence is imposed). 
Colorado Although there are no statutes or court decisions regarding furnishing transcripts to indigent defendants, where a reporter's transcript is necessary for a determination of the issues, it has been the practice [in "capital cases"] for the court reporter to make said transcript and he is reimbursed from county funds." Ltr. of Duke W. Dunbar, Att'y Gen'l of Colorado, dtd. Jan. 22, 1957.

Delaware Although there are no statutes or court decisions regarding furnishing transcripts to indigent defendants, "it has been the practice of our Courts to furnish such transcripts in capital cases. ..." Ltr. of Joseph D. Craven, Att'y Gen'l of Delaware, dtd. Jan. 23, 1957.

Illinois Ill. Rev. Stat. (1955) c. 38, $\$ 769$ a (where death sentence imposed). A transcript is also available in any case arising under Illinois Post Conviction Hearing Act, which comprises cases involving questions arising under the Illinois or Federal Constitutions. Ill. Rev. Stat. (1955) c. 37, \$163(f).

Maine Me. Rev. Stat. (1954) c. 148, $\$ 31$ (applies to any person convicted of murder whether or not indigent).

Maryland Md. Code Ann. (1951) Art. 5, § 89 (where death sentence imposed).

New Jersey N.J. Stat. Ann. (1953) 2A:152-15, 2A: 152-16 (where death sentence imposed).

North Carolina N.C. Gen. Stat. (1953) § 15-181.

Group 4. No Provision for or Established Practice of Furnishing or Makrng Available Transcripts without Charge to ANy Defendants in Any Criminal Cases

Kansas Ltr. of John Anderson, Jr., Att'y Gen'l of Kansas, dtd. July 31, 1956, quoted in 5 Kan. L. Rev. 132 (1956).

Michigan Mich. Stat. Ann. (1943) \$\$27.2516, 27.2614 (appellant must furnish record for appeal).

Minnesota "If the petitioner desires a transcript of such original stenographic record, he must obtain the same from the court reporter at his own expense. The United States Constitution does not require a state to provide the expenses of an appeal for an indigent defendant in a criminal case, and the constitution and statutes of this state neither compel nor authorize such procedure." State ex rel. Koalska v. Rigg, 246 Minn. 234, 74 N.W.2d. 661 (decided Jan. 20, 1956). Griffin v. Illinois was decided Apr. 23, 1956.

North Dakota No statutes or court decisions applicable. "[I]t has always been the view of this office and I think the view of the Bar generally that the defendant was not entitled as a matter of course to a transcript of the proceedings unless he wished to pay for that himself." Ltr. of J. A. Hyland, Ass't Att'y Gen'l of North Dakota, dtd. Jan. 22, 1957. But cf. N.D. Rev. Code (1943) \$29-2818.

Tennessee "[Nothing] in our law relative to the subject. . . " Ltr. of Thomas E. Fox, Ass't Att'y Gen'l of Tennessee, dtd. Jan. 31, 1957. Apparently a full transcript is not necessary for appeal, however, as a majority of cases are heard on narrative bill of exceptions. Brief for Petitioners, at 86, Griffin v. Illinois, 351 U.S. 12 (1956).

Vermont Vt. Rev. Stat. (1947) \$1425.

Wyoming Wyo. Comp. Stat. (1946) §1-628 (Supp., 1955). 


\section{APPENDIX II}

PROPOSED AND ACCOMPLISHED CHANGES IN STATE LAW CONCERNING FURNISHING DEFENDANTS IN CRIMINAL PROCEEDINGS WITH THE NECESSARY TRANSCRIPTS FOR APPELLATE REVIEW SINCE GRIFFIN V. ILLINOIS

Illinois Ill. Supreme Court Rule 65-1 ("Any person sentenced to imprisonment" who is "without financial means with which to obtain the transcript of the proceedings at his trial" will be furnished with the same if "necessary to present fully the errors recited in the petition. ...")

Maine Maine Legis. Doc. No. 695, 98th Legis. (S.P. 257, Feb. 13, 1957), appropriating $\$ 5000$ to be used to defray the cost of operating a system of judicial review of judgments in criminal cases involving felonies for indigent persons who are unable to pay for such review under rules as the Supreme Judicial Court shall from time to time determine to be necessary for the protection of such persons' constitutional rights.

Maryland Case pending: Williams v. State, (in the Court of Appeals of the State of Maryland). The governor has provided $\$ 5,000$ in his budget to pay cost of appellate review for indigent prisoners. Ltr. of Stedman Prescott, Jr., Att'y Gen'l of Maryland, dtd. Jan. 30, 1957.

Michigan Case pending: Applications for leave to appeal to the Supreme Court from denials of petitions for free transcripts of the proceedings and records in trial courts, and applications for writs of mandamus to compel the trial courts to furnish transscripts; these cases are to be consolidated and should shortly be decided. Ltr. of Thomas M. Kavanagh, Att'y Gen'l of Michigan, dtd. Jan. 28, 1957.

Minnesota State v. Haller, 247 Minn. 571, 78 N.W.2d 389 (1956) (dismissing petition for order of Supreme Court directing district court to furnish indigent defendant convicted of grand larceny with trial transcript because court lacked jurisdiction "in the absence of a prior application for relief to the district court"): "Not all errors presented upon appeal require the preparation of a transcript since the judgment roll referred to in $\$ 632.04$; or the bill of exceptions provided for by $\$ 632.04$; or the synopsis of the testimony prepared pursuant to $\$ 640.10$ may singly, or in combination, be sufficient to provide an adequate review in compliance with the due process and equal protection clauses of U.S. Const. Amend. XIV."

New Jersey N.J. Stat. (1953) §§2A:152-17 to 2A:152-19 (Supp., 1957) ("Any person convicted of any crime [upon] showing that a copy of the transcript of the record, testimony and proceedings at the trial is necessary ["for the filing or for appeal"] of any application with the trial court," and that he is "unable, by reason of poverty, to defray the expense of procuring the same" shall be furnished with the same.)

Tennessee S.B. 84 \& H.B. 107, 1957: "In all felony cases where a conviction be had, judgment entered, and an appeal therefrom prayed and granted, if the case is not reported stenographically, it shall be the duty of counsel who represent the defendant at the trial either by employment or appointed to prepare the file a narrative bill of exceptions. ..." (Most cases on appeal are heard on narrative bill of exceptions. Group 4, Appendix I.) This bill apparently was not enacted prior to adjournment of the General Assembly on March 22, 1957. 